\title{
Teaching Video NeuroImages: Acquired focal neuromyotonia in LGI-1 autoimmunity
} A. Sebastian López Chiriboga, MD, Joseph Matsumoto, MD, Eric Sorenson, MD, Christopher J. Klein, MD,
and Andrew McKeon, MD

Neurology ${ }^{\circledR}$ 2018;90:e1636-e1637. doi:10.1212/WNL.0000000000005426

\section{Correspondence}

Dr. Chiriboga

lopez.alfonso@mayo.edu

Figure Physical examination, EMG, and serologic testing
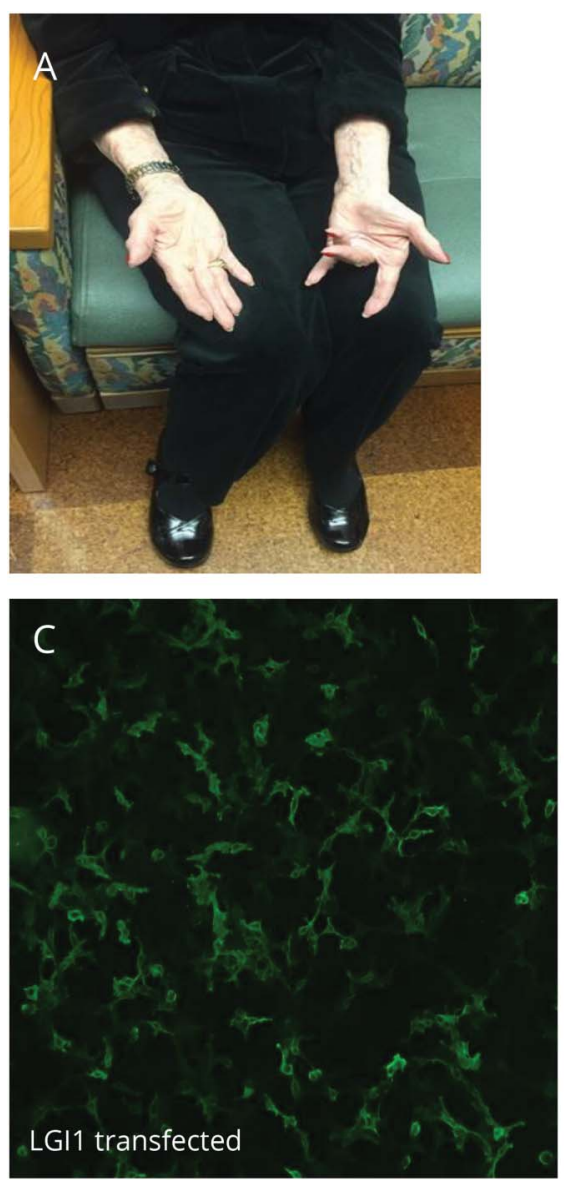
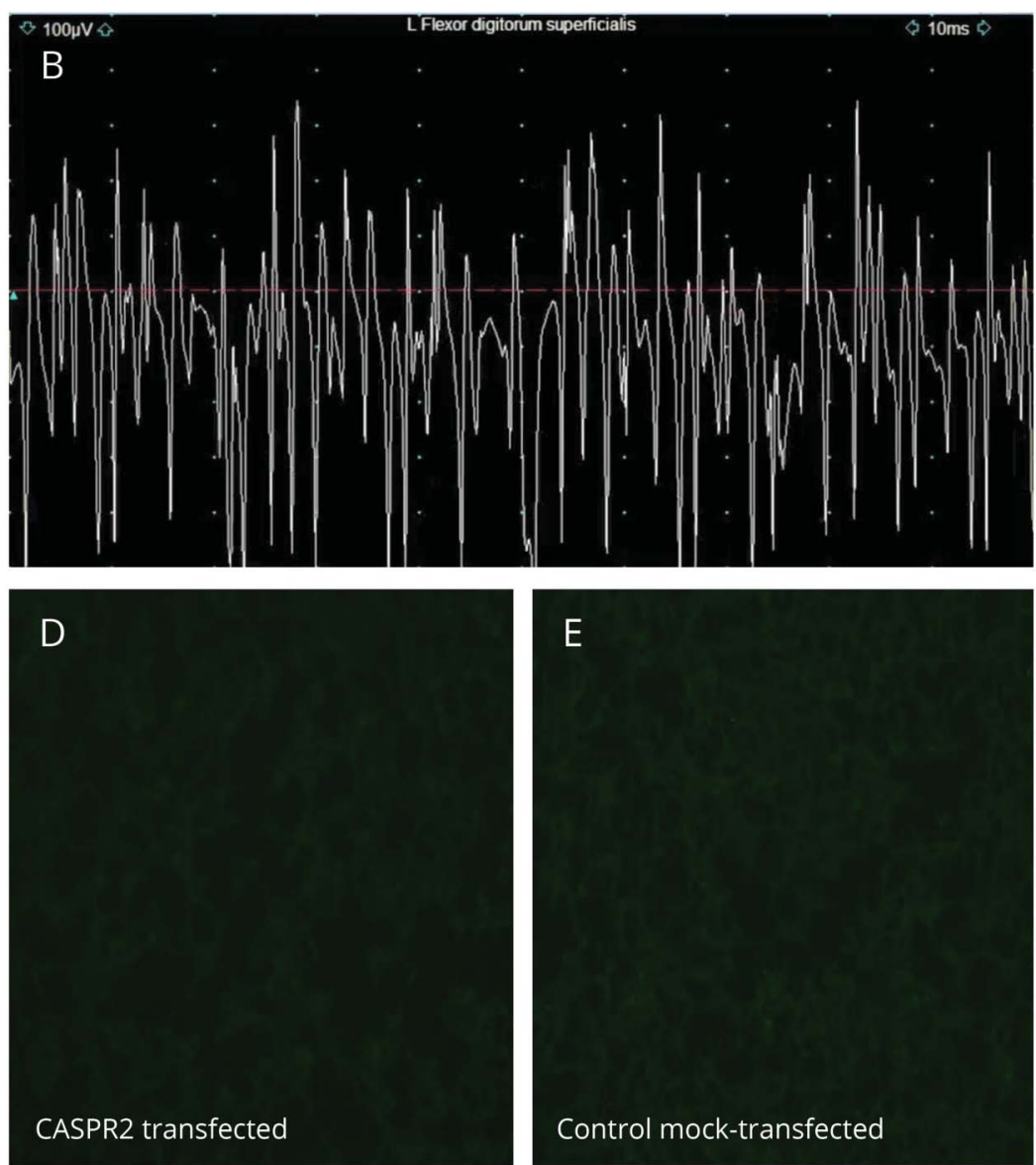

(A) Persistent left III and IV digit flexion. (B) EMG shows abnormal high intraburst frequency discharges. Serum was tested for immunoglobulin G (IgG) reactive with LGI1 or CASPR2 proteins by a cell-based immunofluorescence assay using as substrate fixed HEK 293 cells that were nontransfected or transfected with plasmid-encoding human LGI1 or CASPR2 proteins. We detected bound IgG by use of fluorescein isothiocyanate conjugated goat IgG specific for human IgG. Serum is reactive with LGI1 transfected cells (C), but not CASPR2 transfected cells (D) or control mock-transfected cells (E).

An 81-year-old woman was diagnosed with corticobasal degeneration (cognitive decline and left hand posturing). Hyponatremia and bilateral faciobrachial dystonic seizures (FBDS) ensued. Neurologic examination (figure, A; video) revealed persistent involuntary continuous left $3 \mathrm{rd}$ and 4 th finger flexor activation and delayed relaxation. EMG revealed high-frequency spontaneous discharges, including neuromyotonia and fast myokymia of the left flexor digitorum superficialis and pronator teres (figure, B). LGI1 immunoglobulin $\mathrm{G}(\operatorname{IgG})^{1}$ was detected, but not CASPR2-IgG (figure, C-E). Oncologic evaluation revealed

\section{MORE ONLINE}

\section{$\Theta$ Video}

\section{$\rightarrow$ Teaching slides}

links.lww.com/WNL/A413

From the Departments of Neurology (A.S.L.C., J.M., E.S., C.J.K., A.M.) and Laboratory Medicine and Pathology (C.J.K., A.M.), Mayo Clinic, Rochester, MN.

Go to Neurology.org/N for full disclosures. Funding information and disclosures deemed relevant by the authors, if any, are provided at the end of the article. 
breast ductal carcinoma in situ. Encephalopathy and FBDS resolved after IV immunoglobulin. Encephalopathy coexisting with peripheral nerve hyperexcitability can mimic neurodegeneration, and should prompt exclusion of LGI1/CASPR2 autoimmunity. ${ }^{2}$

\section{Author contributions}

Dr. Lopez contributed to the conception and design of the study; collection, analysis, and interpretation of the data; drafting and critical revision of the article; and generation/collection of the figures. Dr. Matsumoto contributed to the conception and design of the study; collection, analysis, and interpretation of the data; and generation of the figures. Dr. Sorenson contributed to the conception and design of the study; collection, analysis, and interpretation of the data; and generation of the figures. Dr. Klein contributed to the conception and design of the study; collection, analysis, and interpretation of the data; and generation of the figures. Dr. McKeon contributed to the conception and design of the study; collection, analysis, and interpretation of the data; drafting and critical revision of the article; and generation/ collection of the figures. All authors gave final approval of the article.

\section{Acknowledgment}

The authors thank the Mayo Clinic Center for MS and Autoimmune Neurology for research support.

\section{Study funding}

No targeted funding reported.

\section{Disclosure}

A. Lopez Chiriboga, J. Matsumoto, E. Sorenson, and C. Klein report no disclosures relevant to the manuscript. A. McKeon receives research support from and has consulted for Euroimmun, Medimmune, and Grifols, but has not received personal compensation. Go to Neurology.org/ $\mathrm{N}$ for full disclosures.

\section{References}

1. Gadoth A, Pittock SJ, Dubey D, et al. Expanded phenotypes and outcomes among 256 LGI1/CASPR2-IgG-positive patients. Ann Neurol 2017;82:79-92.

2. Irani SR, Alexander S, Waters P, et al. Antibodies to Kv1 potassium channel-complex proteins leucine-rich, glioma inactivated 1 protein and contactin-associated protein- 2 in limbic encephalitis, Morvan's syndrome and acquired neuromyotonia. Brain 2010; $133: 2734-2748$. 


\section{Neurology}

Teaching Video NeuroImages: Acquired focal neuromyotonia in LGI-1 autoimmunity

A. Sebastian López Chiriboga, Joseph Matsumoto, Eric Sorenson, et al.

Neurology 2018;90;e1636-e1637

DOI 10.1212/WNL.0000000000005426

This information is current as of April 30, 2018

Updated Information \&

Services

References

Citations

Subspecialty Collections

Permissions \& Licensing

Reprints including high resolution figures, can be found at: http://n.neurology.org/content/90/18/e1636.full

This article cites 2 articles, 0 of which you can access for free at: http://n.neurology.org/content/90/18/e1636.full\#ref-list-1

This article has been cited by 1 HighWire-hosted articles: http://n.neurology.org/content/90/18/e1636.full\#\#otherarticles

This article, along with others on similar topics, appears in the following collection(s):

Autoimmune diseases

http://n.neurology.org/cgi/collection/autoimmune_diseases

EMG

http://n.neurology.org/cgi/collection/emg

Encephalitis

http://n.neurology.org/cgi/collection/encephalitis

Information about reproducing this article in parts (figures,tables) or in its entirety can be found online at:

http://www.neurology.org/about/about_the_journal\#permissions

Information about ordering reprints can be found online:

http://n.neurology.org/subscribers/advertise

Neurology ${ }^{\circledR}$ is the official journal of the American Academy of Neurology. Published continuously since 1951, it is now a weekly with 48 issues per year. Copyright (O 2018 American Academy of Neurology. All rights reserved. Print ISSN: 0028-3878. Online ISSN: 1526-632X.

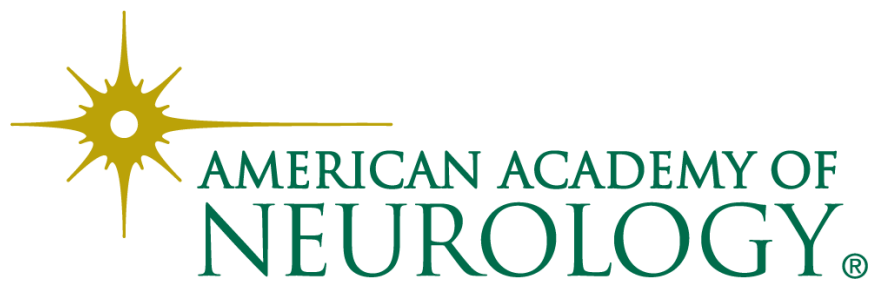

